\title{
Study of Debt Financing of GEM Listed Companies in China
}

\author{
Liu Ran* \\ College of Economics and Management \\ Dalian University \\ Dalian, China \\ e-mail: liuran@dlu.edu.cn \\ * Corresponding Author
}

\author{
Sun Jihui \\ College of Economics and Management \\ Dalian University \\ Dalian, China \\ e-mail: dlsunjihui@163.com
}

\begin{abstract}
Small and medium enterprises (SMEs) have a major role in contributing towards long-term economic growth and employment. The objective of this paper is to investigate the influencing factors of debt financing for the GEM listed companies in China. The current status of debt financing for GEM listed companies was analyzed, and highlights current policies and measures supporting the debt financing for GEM listed companies in China. By learning the experience and successful practices, some measures and suggestions on policy for improving the debt financing efficiency of GEM listed companies was proposed. The study shows that over-investment increases debt financing of a company, while an increasing new debt-financing restrains over-investment of the company. The study is of great help to gain a better understanding of debt financing of GEM listed companies in China and effectively obtain debt financing through external and internal debt financing for GEM listed companies in China by improving the internal corporate governance and external creditors governance, optimizing the structure of corporate finance.
\end{abstract}

Keywords-debt financing; GEM listed companies; internal financing; external financing; corporate governance

\section{INTRODUCTION}

Small and medium enterprises (SMEs) have a major role in contributing towards long-term economic growth and employment. Recently, more and more SMEs are start up with the rapid economic development and increasing social progress in China under economic globalization. According to incomplete statistics, the proportion of the SMEs in all enterprises in China reached $90 \%$ or more, which provides a job demand of about $80 \%$ of urban job employment $[1,2]$. It can be seen that SMEs play a vital role in China's economic development, however, a number of factors such as financing difficulties and in-standardized management limit the growth of SMEs. In particular, debt financing appears to be ill-suited for newer, innovative and fast growing SMEs, with a higher risk-return profile. Bank lending is the most common source of external finance for many SMEs and entrepreneurs, which are often heavily reliant on straight debt to fulfill their start-up, cash flow and investment needs. While it is commonly used by small businesses, however, traditional bank finance poses challenges to SMEs and may be ill-suited at specific stages in the firm life cycle. The financing constraints can be especially severe in the case of startups or small businesses that rely on intangibles in their business model, as these are highly firm-specific and difficult to use as collateral in traditional debt relations. Yet, for most enterprises, there are few alternatives to traditional debt. This represents an important challenge for policy makers pursuing sustainable recovery and long-term growth, since these companies are often at the forefront in job creation, the application of new technologies and the development of new business models. While alternatives to traditional debt finance are particularly important for start-ups, high-growth and innovative SMEs, the development of alternative financing techniques may be relevant to the broader population of SMEs and micro-enterprises.

In the aftermath of the 2008-2009 global financial crises, the bank credit constraints experienced by SMEs in many countries have further highlighted the vulnerability of the SME sector to changing conditions in bank lending [3]. To provide a better development platform for SMEs, the GEM gradually appears in the market, its huge potential for those companies with innovative development provides more convenient financing channels. Finally in October 2009, China officially listed on GEM, in its expansion process, increasing the normative role of innovative enterprises to promote enterprise mobility. As appears more than five years of GEM listed companies to make China's SMEs have tasted the sweetness, but also had to give setbacks, to encourage them to grow [4]. GEM listed company's debt financing structure has an important role in the process of maximizing the interests of enterprises. However, SMEs often face limited access to financing due in part to the relatively higher risks associated with investing in them. The SME financing challenge has been exacerbated following the introduction of significant financial regulatory reforms in the aftermath of the global financial crisis, heightening banks' risk aversion when extending loans. Capital markets therefore have an imperative role in bridging this financing gap through the provision of alternative funding sources for SMEs, particularly as their needs evolve over the different phases of their life cycle. 
TABLE I. FINANCING PROPORTION OF GEM LISTED COMPANIES

\begin{tabular}{|c|c|c|c|c|c|c|c|c|c|}
\hline \multirow[t]{3}{*}{ Year } & \multirow{2}{*}{\multicolumn{2}{|c|}{ Internal financing }} & \multicolumn{7}{|c|}{ External financing } \\
\hline & & & \multicolumn{3}{|c|}{ Debt Financing } & \multicolumn{3}{|c|}{ Equity Financing } & \multirow{2}{*}{$\begin{array}{c}\text { Government } \\
\text { subsidies }\end{array}$} \\
\hline & $\begin{array}{l}\text { Retained } \\
\text { earnings }\end{array}$ & $\begin{array}{c}\text { Depreciation } \\
\text { Expense }\end{array}$ & $\begin{array}{c}\text { Business } \\
\text { Credit }\end{array}$ & $\begin{array}{l}\text { Short- } \\
\text { term } \\
\text { Loan }\end{array}$ & $\begin{array}{c}\text { Long- } \\
\text { term } \\
\text { Loan }\end{array}$ & $\begin{array}{c}\text { Existing } \\
\text { Share- } \\
\text { holders }\end{array}$ & $V C / P E$ & Other & \\
\hline 2009 & $38.21 \%$ & $1.39 \%$ & $22.25 \%$ & $9.98 \%$ & $2.31 \%$ & $11.43 \%$ & $6.66 \%$ & $5.00 \%$ & $2.77 \%$ \\
\hline
\end{tabular}

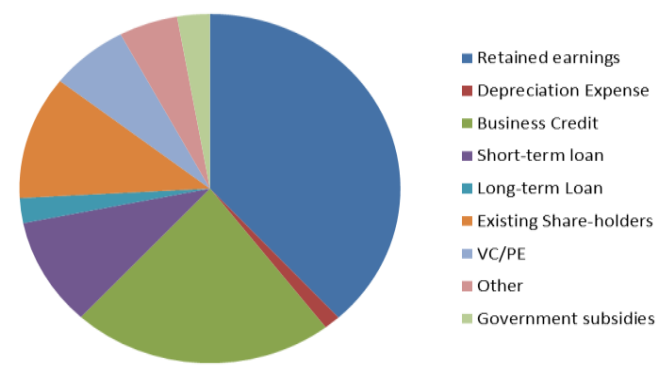

Figure 1. Financing proportion of GEM listed company.

Debt financing is critical to the growth of SMEs. According to Grant Thornton International Business Reports, top managers of privately held companies across 36 countries state that financial constraints are a significant barrier to business expansion and that the top three benefits of financial reporting include greater transparency, reduced costs, and easier access to capital, suggesting that debt markets provide private firm managers with incentives to improve accounting quality for efficient financing. Despite the economic importance of debt financing for SMEs, little is known about how SMEs respond to debt holder demands for high-quality financial reporting. Existing theories about a lot of debt financing, in view of the GEM listed companies remain in the theoretical study of the basic research stage, this article will focus on exploring the current situation through debt financing, debt financing careful to structure the company to explore, to find it in the debt financing for influence the development of prosperity GEM listed companies, and electronic communications company - Wu-communications company, for example, try to improve the results of the analysis conducted by confirmed cases. I hope this is the breakthrough point, the theoretical financial leverage, solvency, and many other data from the analysis, the development process to help companies find the problems and propose countermeasures. GEM listed company debt financing plans make some contribution to the development of analysis, it is desirable to make the reader through a case on this issue more clearly.

It is therefore necessary to broaden the range of financing instruments available to SMEs and entrepreneurs, in order to enable them to continue to play their role in growth, innovation and employment. Financial stability, financial inclusion and financial deepening should be considered as mutually reinforcing objectives in the quest for sustainable recovery and long-term growth.

\section{CURRENT STATUS OF DEBT FINANCING}

\section{A. Way of Debt Financing}

Debt financing generally can be divided into external financing and internal financing in the theory of capital structure. External financing is any kind of business funding you acquire from sources outside the firm. It is contrasted to internal financing which consists mainly of profits retained by the firm for investment. There are many kinds of external financing. Bank loans, investments from private individuals or investment firms, grants and selling company shares are all examples of external financing. The two main ones are equity issues, (IPOs or SEOs), but trade credit is also considered external financing as are accounts payable, and taxes owed to the government. External financing is generally thought to be more expensive than internal financing, because the firm often has to pay a transaction cost to obtain it.

One of the advantages of external funding is it allows you to use internal financial resources for other purposes. If you can find an investment that has a higher interest rate than the bank loan your company just secured, it makes sense to preserve your own resources and put your money into that investment, using the external financing for business operations. You can also set aside your internal financial resources for cash payments to vendors, which can help improve your company's credit rating. Part of the reason organizations use external funding is it allows them to finance growth projects the company could not fund on its own. External funding can be used for making large capital equipment purchases to facilitate growth that the company cannot afford on its own. Some sources of external financing, such as investors and shareholders, require you to give up a portion of the ownership in your company in exchange for the funding. You may get that large influx of cash you need to launch your new product, but part of the financing agreement is the investor is allowed to vote on company decisions. This can compromise the vision you originally had for your company when you founded it. External funding sources require a return on their investment. Banks will add interest to a business loan, and investors will ask for a rate of return in the investment agreement. Interest adds to the overall cost of the investment and can make your external funding more of a financial burden than you had originally planned.

TABLE II. SUMMARY OF GEM LISTED COMPANY'S FINANCIAL DATA IN 2011-2012

\begin{tabular}{|l|c|c|}
\hline \multicolumn{1}{|c|}{ Year } & $\mathbf{2 0 1 1}$ & $\mathbf{2 0 1 2}$ \\
\hline Current liabilities & 200.01 & 148.57 \\
\hline Non-current liabilities & 19.94 & 14.80 \\
\hline
\end{tabular}

Debt financing for companies listed on GEM has been an advantage, its preferential policies for enterprises to provide lower financing threshold, but in the selection of debt financing problems, is still an important issue worthy of consideration. Table 1 lists debt financing structure of the first companies listed on GEM. According to Table 1, we can find that the value of the internal financing is much higher than that of external financing and internal financing is the first choice for most companies. The 
reason for that is the time of listed company's market development is shorter, and its scope is small. It is still in the stage of development and the experience was not so enough since 2009. It will take a long time to expand production and thus restrict the development of enterprises if it is completely dependent on internal financing. Thus, an appropriate debt financing structure of enterprises will make enterprises high-speed and stable growth in the competition.

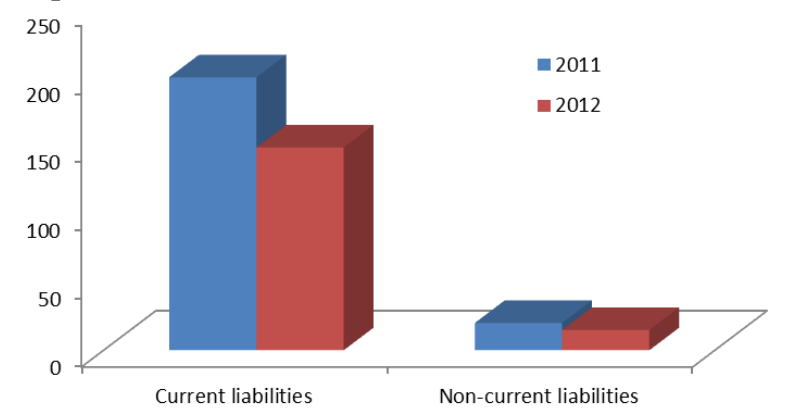

Figure 2. Financing liabilities of GEM listed company in 2011-12.

Since GEM listed companies has been established to give companies the pro-Lai in the market, to make progress in the process of GEM listed companies more obvious, the state has adopted new regulations to regulate GEM listed companies, which has a debt ratio would require the end of the current issue higher than $45 \%$ can be re-financing, this rule came out, the discussion of GEM companies on the market once again become a hot, obviously, the GEM Listing financing standards lower than the motherboard market is a preferential its SMEs, But refinancing conditions increased, but also encourage these companies to quickly develop, does not live up to expectations. By the end of 2014, according to incomplete statistics of the data, asset liability ratio over 100 enterprises in 30 percent, only 43 more than 45 percent, compared to 75 companies are excluded, such stringent conditions, which also give a spur GEM listed companies, which will help them choose the right debt financing, make good use of funds and reduce financial risks and liabilities of the company, enabling the company to sustained and stable growth, make good use of the preferential policies granted by the State, not just freeloaders. Therefore, to understand the GEM listed company's debt financing issues, the saying goes, "Know thyself, know yourself" and take advantage of financing and improving balance was to lay the foundation for better development of enterprises.

\section{B. Debt financing Structure}

Debt financing structure refers to the composition and ratio of all debt capitals of company. It has close relations with the corporate management, corporate value. Independent research and innovation has been embodied in the specialties of GEM listed company, but we must also clearly realize that debt financing structure is bound to be one of the factors to be considered. Liabilities can be divided into current and non-current liabilities. Table 2 shows the composition of financial data in the year of 2010 and 2011. It can be clearly seen that the ratio of current liabilities in the total liabilities is high. As far as we know, if a company has a high ratio of current liabilities in the total liabilities in the production process, the company will undertake large loan interest liabilities due, and it has to have a continuous flow of funds for a rainy day, meanwhile it will increase its financial risk. On the contrary, if the company has adequate long-term credit liabilities, it is helpful to carry out some research and development of product in a very long period of continuous cycles and increase the market share of the company.

Through the analysis of GEM listed company's debt financing structure, it is found that a small change of the GEM listed companies will greatly affect the increase or decrease of financial risk, which in turn means that the financial risk of GEM listed companies has a great impact on GEM listed companies. It further proves that the company's financing structure is closely related to the size of the company's financial risks. It also requires the companies listed on GEM take over the advantages of innovations to prompt the sustainable growth of companies.

\section{Enterprise Development Efficiency}

Any company must first have a lot of money to enable the company to have more working capital to maintain sustainable development. The company gets financing funds through the company's resolution in various ways and increases the owner's equity of the company by way of investment. The dividends can be paid by companies under an appropriate management.

Currently, the GEM listed companies generally adopt a liberal financial management policy, making enterprises to have sufficient funds to carry out the operation in difficult times. Meanwhile, decision-making is very important during the company's development process, requiring a proper resolution on the way and the structure of debt financing. This can help the company to have the best management efficiency and make better development. Reasonable debt financing not only for the work efficiency of the company plays a role, but more importantly is to fully utilize the debt financing will at the same time bring huge benefits to the enterprise, and will not allow companies facing bankruptcy. Reasonable internal management, will also promote the efficiency of debt financing, to rectify both from inside and outside the company, so that enterprises in a dominant position in the competition.

\section{BUSINESS DATA ANALYSIS-BASED DEBT FINANCING}

GEM listed companies who have the potential of innovative companies in the market, which typically have electronic communications business enterprises, "the existence of the communications industry by its nature, high-tech development is to ask him, in order to enable enterprises to continue to make breakthroughs, One is the standard for enterprise development of innovative technologies, such as the nature of force in the study of the technical aspects of the communications industry have to invest a lot of money as a technology investment. "[5], but also shows the rapid development of the electronic communications industry makes its debt financing mode the more stringent requirements, the complexity of its debt financing structure is self-evident. High-tech research, is bound to consume most of the company's funds, and internal financing sometimes cannot meet the company's 
demand, some companies tend to make the company has more capital by issuing shares, etc., on the other hand this also makes reduce equity within the company, it has more restrictions on the rights of existing shareholders, which is not conducive to the company's management, and increase their capital through debt financing is not involved in this case. In recent years, the development of its debt financing and corporate governance closely, improving corporate debt financing issue is currently difficult problem, so that it is more conducive to development.

\section{A. Effect of Financial Data on Debt Financing}

Enterprise management efficiency is the basis of production and management for a company. It is not only an internal program management of a company, but also a manifestation of company supervision. Loose internal supervision will make credit and other aspects of the company cannot improve and lead to some problems about debt financing efficiency. It can be seen that earnings per share is one of the indicators to judge business conditions of a company. For a company with high earnings per share, it can get better credit and help to raise more long-term liabilities, and thus it will have appropriate debt financing structure. The future development prospects of the company can be foreseen from the company's debt financing structure. It means that the flow of debt financing and non-current proportional distribution should be reasonable. But the size of current liabilities depends on the size of the company's solvency; the size of business credit is also dependent on the long-term bonds. It can be analyzed by the solvency of enterprises, to determine the appropriate corporate debt financing structure.

There are a variety of ways in debt financing, how to choose one of them depends on specific analysis of the company's operating conditions and other factors. Assetliability ratio is closely related to financial leverage and shows a positive relationship. The companies must have sufficient funds to carry out the operation and at the same time requires the companies to be able to afford a greater risk in the growth trend. To remind the business to be able to make full use of the funds, otherwise it will have a negative effect. Asset-liability ratio is an indicator of capital structure, asset-liability ratio is too large, it indicates that the company does not operate well and it could lead to bankruptcy [6].

Meanwhile, the greater the financial leverage coefficient, the more prominent the impact of the company's pre-tax profit per unit of volatility will bring. It means that once the business units have little fluctuations on pre-tax profit companies will bring huge benefits. In the development process of GEM listed company, the GEM listed company analyzes the size distribution of financial leverage and constantly adjust fluctuation levels of financial leverage from the company's financial leverage. It also shows that the financial leverage has two sides [7].

\section{B. Existing Problems in Debt Financing}

Innovation has become the main development direction with the development of the times. The country encourages GEM listed company to form in our market in order to support the part of the enterprise. There are external and internal factors about GEM listed company's debt financing issues as well as risk factors. GEM listed companies, different from other companies, are not so perfect and need to gradually enrich. We have to consider the impact of its external and internal factors in the process of development. Individual enterprise view pointed out that from the macro and micro regulations based on careful analysis of the government, in order to improve China GEM listed companies use equity financing efficiency of suggestions and strategies in all aspects of debt financing to close, one can be a financing over inappropriate manner [8]. Debt financing structure conforming to the enterprise will help to make the normal operation of enterprises and contribute to development of the company. In other words, the causes of its excessive financing for a debt financing model should be taken into account to develop appropriate financing model [9].

Depending on the company's equity restrictions, the need for equity perfectly reasonable for corporate governance and efficiency improved debt structure to another level [10]. The impact of financial risk on the enterprise channel financing ways is analyzed in the study of GEM listed company's debt financing issues. Considering all aspects of the financial risk of the impact of corporate debt financing reasons, the structure of debt financing research, analyze their impact on the GEM listed companies found. Meanwhile, various studies show that the impact of debt capital structure model of financing structure, and debt financing and business development and is closely related to these two issues are key issues in the development of business to be addressed. Not all companies listed on the GEM after all plain sailing, once financing is successful, the next would be to find how to use the funds for the company to get huge benefits. The study found that GEM listed companies following several defects will make the company unable to maximize the value of the benefits. GEM listed companies form less than six years, compared to the foreign mature patterns, our GEM listed companies need to learn a lot of foreign development experience on their development process. And it has the potential for the company to promote a market economy in the development model, but the company cannot reasonably use the financing to achieve maximum benefits.

The causes of financial risks are largely due to the imbalances of the financing structure in the development process of the company [11]. Debt financing has a critical role in the development of enterprises. The most reasonable debt financing structure can only be obtained under the premise of the optimal capital structure. It also requires companies to always deal with the problems and make the appropriate protective measures. The best model for enterprise capital structure determination is favorable impact on the company's debt financing. Most companies listed on GEM without a sound system cannot make full use of the capital in early stages of development, leading an internal confusion in the company and an imperfect of the use of internal funds. The long-term credit-based credit places, also led to no good faith basis for GEM companies cannot be long-term credit, as opposed to shortterm loans, the long-term lending interest rates relative to the lower, and in the enterprise development stage would be a very Great way to obtain funds, may make the company subjected to great loss. The key to the credit for a company is to establish a good morality. Once the morality is established, the credit problem is thus solved. 


\section{WAYS TO IMPROVING DEBT FINANCING EFFICIENCY}

\section{A. Seeking Practical Experience for SteadyDevelopment}

GEM listed company in China is still very young, but has a long history in foreign countries, also after several years of experience precipitation, foreign GEM listed companies mature, our GEM early there is a good start, the company's innovation make the GEM hot, relative to other countries of the GEM market, we are still in the development stage, seeking mature development experience, so we do not take too many corners, so to foreign companies listed on GEM progress of exploration and practice experience not a bad idea. And then we can learn from overseas failed Cause: listing standards too low, because of the environment allows the company structure cannot meet the long-term development and so on. After several years of development, foreign companies come to experience to ensure market liquidity was favorable development, which requires us to GEM external markets to become rich and perfect, is more favorable for the company's development. On the other hand, the company's supervision should be strengthened, so that will make up the various aspects of rigor, but also for the funds to make a full use of the financing system security.

\section{B. Taking Advantage of Financing Funds and Limiting Short-Term Behavior}

Make full use of corporate funds will bring more benefits, so that investors see business prospects infinite, but also timely repayment of debt, distribution of dividends, increase their credit, so that all aspects to achieve the optimum configuration for the next financing lay a good foundation, but also enables companies to have a good business development capacity. Second, the implementation of a standard system, or should emerge as the introduction of favorable policies to stimulate the development of enterprises limited power at the same time, make more and more standardized GEM market, also limits the short-term behavior.

\section{CONCLUSIONS}

Although the financing through the issuance of stocks and bonds will increase the company's ownership interest, but you have to show their strength to other investors and give great credit rating. But everything has a degree, once the liabilities exceed the boundary value, increased risk, the company will be faced with the threat of bankruptcy. Every business has one of their own internal debt financing structure, operations and debt financing structure of enterprises so they can maintain a balance of truth, mutual promotion and mutual restraint development.

Based on the company's financial leverage, solvency analysis and study, found through debt financing allows businesses to have more money to run, but the company must be aware of the company's future development, do not let the funding is much higher than solvency, or else irrational financing plan will bring certain risks. GEM listed companies have a characteristic, that is part of its financing mostly from the outside, a relatively small internal financing, but also makes important financial form GEM listed companies by current liabilities on bond financing. However, the double-sided nature of financial leverage reminder when conducting financing company have sufficient funds use plan, an appropriate increase in earnings per share, so that financial leverage is maintained at an appropriate level, but also requires companies to conduct adequate debt financing, enabling the company development of. By analyzing the company and to solve the problems, while the debt financing structure to integrate and improve enterprise asset-liability ratio, also better able to refinance, GEM listed company by improving the internal management of the environment, access to proper proportion of debt financing, financing capital increase utilization, and to establish reasonable debt financing models, has a positive impact on the long-term development of the company.

\section{ACKNOWLEDGMENT}

The joint support provided by Fundamental Research Funds for the Central Universities (N130501002) is highly acknowledged.

\section{REFERENCES}

[1] M. Campello, "Debt financing: Does it boost or hurt firm performance in product markets?," Journal of Financial Economics, vol. 82, pp. 135-172, 2006.

[2] R. H. Chowdhury and M. Maung, "Corporate entrepreneurship and debt financing: evidence from the GCC countries," International Journal of Managerial Finance, vol. 9, pp. 294-313, 2013.

[3] C. Florackis, A. Kanas, and A. Kostakis, "Dividend policy, managerial ownership and debt financing: A non-parametric perspective," European Journal of Operational Research, vol. 241, pp. 783-795, 3/16/ 2015.

[4] H. Gonenc, "Comparison of debt financing between international and domestic firms," International Journal of Managerial Finance, vol. 1, pp. 49-68, 2005.

[5] J. K. Ko and S.-S. Yoon, "Tax Benefits of Debt and Debt Financing in Korea," Asia-Pacific Journal of Financial Studies, vol. 40, pp. 824-855, 2011.

[6] V. Mande, Y. K. Park, and M. Son, "Equity or Debt Financing: Does Good Corporate Governance Matter?," Corporate Governance: An International Review, vol. 20, pp. 195-211, 2012.

[7] M. Massa and L. Zhang, "Monetary policy and regional availability of debt financing," Journal of Monetary Economics, vol. 60, pp. 439-458, 5// 2013.

[8] E. Selvarajah and N. Ursel, "Mergers and corporate debt financing," Economics Letters, vol. 114, pp. 296-298, 3// 2012.

[9] T. Tanaka, "Corporate governance and the cost of public debt financing: Evidence from Japan," Journal of the Japanese and International Economies, vol. 34, pp. 315-335, 12// 2014.

[10] Y. Yang and J. Yang, "A Decision Engineering Problem for Operating Diversification in Debt Financing Constraints," Systems Engineering Procedia, vol. 3, pp. 179-186, // 2012.

[11] D. Yazdanfar and P. Öhman, "Debt financing and firm performance: an empirical study based on Swedish data," The Journal of Risk Finance, vol. 16, pp. 102-118, 2015. 